István Stumpf

\title{
The Hungarian Constitutional Court's Place in the Constitutional System of Hungary
}

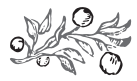

\section{Summary}

This paper presents the achievements of the "Rule of Law Revolution" and the role of the Constitutional Court in the different stages of Hungary's rule of law evolution. Special attention will be placed on the current Hungarian practice of rule of law, the topics of rule of law, constitutionalism and the division of powers within the framework of legal and political constitutionalism will be discussed. The paper also will summarize the views that criticized the activism of the Hungarian Constitutional Court, and those that have laid down the groundwork for the expansion of political constitutionalism after the 2010 Parliamentary elections. Finally, the challenges of rule of law and constitutionalism will be examined, with regard to the role of the Court as the principal organ for the protection of the Fundamental Law in the context of Hungary's membership in the European Union.

Keywords: constitutional court, Fundamental Law, fundamental rights, decisions of the Court

Dr István STUmpf, professor, Széchenyi István University, Győr, judge, Justice of the Constitutional Court of Hungary (stumpf@mkab.hu). 


\section{The position of the Constitutional Court IN THE DIVISION OF POWERS}

In Hungary's previous legal system, the principle of the division of powers was only mentioned in the preamble of the Act on the Constitutional Court. The Fundamental Law, however, explicitly sets forth the principle of separation of powers: "the functioning of the Hungarian State shall be based on the principle of division of powers." (Article C paragraph 1).

Following the regime change, although the principle of separation of powers was not explicitly mentioned in the Constitution, but the Constitutional Court has consistently enforced it in its decisions as an integral part of the rule of law. ${ }^{1}$ Unlike the welldeveloped system of the rule of law, the Constitutional Court did not give a detailed description of the separation of powers, rather the Court expressed their opinion in connection with a specific case. Therefore, when defining its own legal status in the early period of its functioning, the Constitutional Court ruled that when exercising powers directed to specific parts of the Constitution, the principle of division of powers has to be taken into consideration, as one of the most important organizing and functional principles of the Hungarian governmental system. ${ }^{2}$ The Constitutional Court consistently rejected the idea of taking the responsibility of the government or the legislature onto itself in connection with preliminary norm control ${ }^{3}$. The Court accepted the traditional three-part division of the branches of government, mostly because of a practical consideration, rather than a theoretical one, thus making it obvious that they would not follow the latest fashion of discovering more and more branches of power (media, local governments, unions).

In its landmark decision on the appointment of judicial leaders, the Constitutional Court defined the characteristics of the judicial branch in the system of powers. "When interpreting the principle of the separation of powers (as a part of the rule of law) the Constitutional Court based its decision on the way the principle of separation of powers is used in today's parliamentary systems, and on the way it is written in the Constitution. The 'separation' of the legislative and executive branches today basically means the division of powers between the parliament and the executive branch, although they are politically connected. The parties in the governing majority of the parliament are entitled to form a government, and the parliament votes on the bills the government introduces. [...] Under these circumstances the main character of the judicial branch, as opposed to the other two 'political' branches, is that it is constant and neutral [even if the judiciary enforces the bills and decrees that are often created to enact political programmes]. This neutrality is expressed by article 50 paragraph 3 of the Constitution by declaring that the judges are independent and are only subordinated to law. [...] Therefore the judicial branch is independent from the political motivations of the other two branches, and in this sense it is constant and continuous. Hereinafter the Constitutional Court interprets the neutrality of the judicial branch as described above." ${ }^{4}$ Early decisions of the Constitutional Court show that the Court interprets the separation of powers not as a hierarchical relationship 
but as a balanced system of mutual control mechanisms. Besides the separation of powers, the Constitutional Court also emphasized the obligation to cooperate: "From the principle of the rule of law (Article 2 paragraph 1 of the Constitution) comes the obligation of the institutions described in the Constitution to carry out their constitutional powers with bon a fide, in cooperation, mutually helping each other." ${ }^{5}$ Finally, I would like to cite a decision concerning the separation of powers that was made under the socialist-liberal coalition government,that won a two-thirds majority in the 1994 election. In this decision the Court committed itself to principles that became the center of attention twenty years later.

"The separation of powers not only means that one branch cannot take the powers of the other, it also means that in a democratic state based on the rule of law there is no unlimited and unlimitable power, therefore some branches do limit the powers of other branches." ${ }^{6}$

\section{HOW CAN WE DEFINE THE ACTIVISM of the Hungarian Constitutional Court?}

When the founding generation left the Constitutional Court, several evaluations were made on the work of the Court. Every one of them emphasizes the activist approach of the Court and the metaphor of the "invisible constitution". Many members of the Constitutional Court did not consider the text of the Constitution, which was enacted in the turmoil of the system change and was intended to be only temporary, such a masterpiece that could not have been enhanced by the law professor members of the Court. It is not surprising that the founding president said the following in an interview later: "for the sake of coherence our constitutional jurisdiction - especially in difficult cases - is often bordering constitution-making, I never denied that" (Sólyom, 2000). Although the Court was divided when it came to the interpretation of its own role, the majority believed that in the given historical situation the Constitutional Court had to have an activist role. President of the Constitutional Court László Sólyom expressed the concept of the "invisible constitution" in his concurring opinion attached to the Court's ruling on death penalty: "The Constitutional Court has to continue its work to formulate in its interpretations the fundamentals of the Constitution and the rights it contains; to create a coherent system with its decisions over the Constitution that is often amended for short-term political interests; as an "invisible constitution" it serves as a solid constitutional measurement, and therefore it surely will neither contradict the Constitution to be adopted, nor any future constitutions." 7

It is definitely unprecedented that a "doctrine" written in a concurring opinion should have such a career. Even the author of this opinion thinks that many people misinterpreted the point of his argument, because the metaphor of the "invisible constitution" is not a synonym of the "eternity clause", on which basis even the written constitution could be taken under critical revision. Rather he wanted to point out that the constitution is something much higher than technical norms: it is a strict order of 
the principles laid down in the decisions of the Constitutional Court. In its decisions the Court has to express, make visible, and use these principles as a coherent system. It is worth noting that in future decisions, the Court avoided even using this metaphor, making sure that their decisions can be connected directly to constitutional rules, and the Court avoided the appearance that its decisions would mean a revision of the written constitution. Nevertheless, the spirit of the "invisible constitution" lived on in Hungarian legal culture, as well in the jurisdiction of the Court.

The functioning of the Constitutional Court was characterized by constant conflicts with the government. After serious internal debates, the Constitutional Court defined its role as a real counterbalance of the parliamentary majority. The Court acknowledged the Constitution as an absolute measure above the Court, a measure which was originally enacted by the parliament. Until 2011, the majority of the Court held that the Court does not demand the power to review the contents of a constitutional amendment, although - as a silent dissenting voice held - "theoretically it could be justified." During the era of the Horn-government which held a two-thirds governing majority between 1994-1998, the governing parties were preoccupied with the constitutional veto of the Bokros-package (a series of drastic cutbacks on the postcommunist welfare system), with the idea of a new constitution, not with the interpretation of unconstitutional amendments of the Constitution. Already during this time, there were lively debates on whether the parliamentary supremacy based on people's representation, or the constitutional control safeguarding fundamental rights should be the guiding principle of public affairs. These debates got heated during the time of the second Orbán-government, which had a two-thirds majority.

In the academic discussion, there is no uniform definition of the Constitutional Court's activism. "Most of the time it reflects disapproval: the Court does not hold on to the text of the Constitution, ignores the precedent, used an unacceptable method of interpretation, invaded the territory of legislation, or just made a decision that the critic disapproved on political grounds. The opposition of the constitutional jurisdiction holds that the whole idea of constitutional revision of the parliament's acts is activism" (Tóth, 2009:17). The debate got more attention in recent years through papers of academics supporting political and legal constitutionalism. ${ }^{8}$

Activities of the Constitutional Court got into the center of attention both in Hungary and abroad. The methods of constitutional interpretation served as an example for other countries as well (South Africa, Lithuania, Ukraine, and Albania). Although many critics accused the Court of importing German law, the competences of the Constitutional Court did not contain the German type of constitutional complaint, the review of court decisions. The Court was believed both in Hungary and abroad as "the most active and the most powerful constitutional court in the world" (Brunner, 1992:539). The most important decisions of the Court (abolition of death penalty, decisions on compensation and transitional justice acts, drawing the line between the competences of the president and the executive) often generated strong political reactions, sometimes even anger. According to critics, the Court only chased the acknowledgement and legitimacy provided by the West in the early nineties, and did 
not show any empathy for everyday reality from its "ivory tower". According to Csaba Varga, one of the most radical critics of the Constitutional Court: "the Court encroached on the whole political process, and in many cases it determined the course of the process, therefore they forced the whole society, the political class, the parties and among them the legislative, executive, and judicial branches that represent society under their arbitrary philosophies, views, and the obligations and restrains that go with them; therefore restraining the chances of a will to change the system - a will to substantially overcome the past and enter into a new phase of nation building" (Varga, 2006:540) Varga claims that the professorial style of the Constitutional Court shackled the system change with its "devastating liberal doctrinaireism". They created an invisible constitution out of mere abstraction, and based on foreign law. By creating constitutional principles themselves, on which basis they nullified the will of the sovereign, they carried out an unconstitutional protection of the constitution. As opposed to the legal nihilism of the one party state they fetishized law, putting the rule of law in the center of the new catechism. The decisions of the Constitutional Court were irrevocably built into the legal system that acquired constitutional power.

Beside the general criticism, the most important decisions of the Court, such as the so-called "transitional justice act" decision, invoked especially heated reactions. Zsolt Zétényi, one of the co-sponsors of the "justice act" which would have lifted the statute of limitation for crimes under communism that were not prosecuted for political reasons, proposed the following argument during the parliamentary debate: "Rule of law should not be a shield against injustice. Restoring the rule of law has to mean punishing capital crimes, so that no criminal offence shall remain unpunished. [...] Limitation and the general principles of the rule of law are not intended to perpetuate or transfer unlawful or pre-law conditions. Summarizing: rule of law regulations have to apply in a rule of law state, but not in a way that it means excluding unlawful conditions from the scope of criminal justice forever. I do not doubt the logic of the argument that the requirements of formal law are violated by the above method, but I do doubt that in this case there is no other way than doing nothing. [...] In a country where law was trampled upon it would be like slapping rule of law in the face to use these exact same trampled upon laws against natural law." Supporters of the bill tried multiple times to help justice triumph over formal rule of law but all of their attempts have failed the test of the Constitutional Court.

From among the first professional critics of fundamental rights activism the fivepoint criticism of Béla Pokol is worth noting:

"1. Activism overtly transfers the weight of the most important decisions affecting the society from the parliament to the Constitutional Court, therefore it erodes the fundamentals of the parliamentary system based on elections and the parliament.

2. The favorite fundamental right formulas of activism are the most abstract constitutional declarations with no normative directions behind them - being at least covered by the consensus of some circles of legal professionals. Therefore activism has no more legitimacy than the inner moral bravery of a constitutional judge. The argument, which is sometimes used in the context of forcing the parliament to the 
background, that "this way the logic and predictable arguments of law take the place of political fights", is completely unfounded.

3. In activism deduction from abstract principles takes the place of the compromising ad hoc decision making mechanism of a pluralist political system, and this paralyzes society. This decision making method is unable to harmonize the thousands of inner conflicts of a complex society, and is therefore also unable to maintain society through it.

4. The appearance and gaining strength of constitutional jurisdiction in matters of fundamental rights in the past 40 years in the western world has brought tension to the traditional texture of law: the cooperation of political legislation, legal dogmatic processes, and formulation of law by courts. Activism dangerously enhances this tension, making fundamental rights "dynamites", which will eventually damage the legal system.

5. Finally the above mentioned problems in the Hungarian political system may lead to the point where major political forces consider cutting back constitutional jurisdiction, or, in radical movements, completely abolishing it. Activism is dangerous not only to the political system and parliamentarism, but to the institution of constitutional jurisdiction itself" (Pokol, 1992:154).

Beside frontal attacks the group of friendly critics could be seen, most of whom considered fundamental rights activism acceptable, or even supportable, while in matters of the scope of jurisdiction and the organization of the state they considered sticking to the text of the Constitution primarily. ${ }^{10}$

In his analysis of constitutional democracy János Kis identified three types of activism (Kis, 2000:112-114). In his view, activism in the scope of jurisdiction is when the Constitutional Court starts a procedure or makes a decision to which they weren't entitled by law, as well as when they broaden the scope of inquiry to legal acts not challenged by the original proposal. Activism of interpretation is when the Court doesn't just use the Constitution, but changes or amends its regulations, most often by comparing the legal act in question to rules not explicitly written in the Constitution. If the Court makes a decision that is biased on the grounds of political reasons, we talk about activism based on political bias. János Kis thinks that the border of fundamental rights interpretation should be drawn somewhere beyond traditional legal positivism, but not as far as to reach natural law, therefore not making it possible to overrule the text of the Constitution on moral grounds. Arguing with Béla Pokol, Gábor Halmai, who subscribes to Dworkinian ideas, protects fundamental rights activism on moral grounds, but criticizes activism in the field of the scope of jurisdiction and the governmental system: "judges should decide on concrete cases not only on the ground of the words of the Constitution but based on principles formulated from the abstract clauses of the Constitution. Activism in the sense of founding arguments based on such principles will probably not be taken away from constitutional jurisdiction" (Halmai, 1994:85).

The debate didn't bring consensus as regards to the question of what theoretical basis does supporting fundamental rights activism and rejecting activism in the 
scope of jurisdiction have. As Gábor Attila Tóth put it:"the question is not whether there exists an acceptable form of activism, but whether the solutions supported by fundamental rights activists are equal with amending or rephrasing the Constitution" (Tóth, 2009:24).

\section{The REVOLUTiOn OF POLITICAL CONSTITUTiONALIST ARGUMENTS}

The 2010 elections brought a landslide victory for the Fidesz-KDNP coalition. The governing forces, having the majority to adopt a constitution, began preparing a new constitution. The strategic decision-makers of Fidesz have long prepared to do away with a system based on the compromises bargained by the economic, political and philosophical elite of the status quo elite, and to break the "clotted post-communist structures" ${ }^{11}$ Analysts close to the national-conservative side kept emphasizing, that "what was carried out on the behalf of the rule of law by limiting multi-party parliamentarism, is considered as choking democracy today." ${ }^{12}$ They believed that serious distortions have happened within the constitutional system, drastically limiting the governments' scope of action. Therefore excessive separation of powers is to be cut back, in order to restore the supremacy of the elected parliament, and to build a strong government with an effective public administration. Several proposals were formulated to change the constitutional system and to introduce innovations to the new constitution. ${ }^{13}$ Some analysts suggested radically breaking ties with the previous era, and initiated a rehabilitation of "the doctrine of the Holy Crown", and the restoration of the legal continuity that was broken by the Soviets taking away Hungary's historical constitution. Others thought that the progress of the new rule of law system is a dead-end, arguing that "constitutionality and rule of law cannot be created otherwise than as a particular answer to a particular challenge" ${ }^{14}$ therefore it is time to stop copying foreign examples. Behind the European Union's attack of the Prime Minister Orbán was the PM's effort to re-politicize political matters and to enforce the mandate given to him by the majority of voters. This contradicted the main trend of European Union politics of turning political matters into legal problems, meaning that solving social problems should happen in the legal/judicial arena. "European politics characterized by the extreme dominance of human rights logic and the downright limitation of the majority principle is in sharp contrast with the principle of total sovereignty of a one-party parliamentary majority" (Pócza, 2012). This argumentation is the main pillar of political constitutionalism.

The adoption and the amendments of the Fundamental Law of Hungary show that the national-conservative majority seized the "constitutional moment" ${ }^{15}$ and carried out the largest scale reform after the system change as regards to the contents and the structure of the Hungarian legal system, in many points motivated by criticisms of the previous constitutional system. The Fundamental Law, adopted exactly one year after the 2010 elections, was intended to symbolize - even in its name breaking with the previous system based on the pacts of the old elite. A new political generation introduced its demand for position that is not bound by the compromises 
of the previous era, that doesn't accept "nullifying" the historical constitution, considers the importance of the family in maintaining the community, and does not give up the idea of uniting the nation without moving the borders. The preamble of the Fundamental Law, the National Avowal, symbolizes breaking with the former, politically neutral constitutional identity. ${ }^{16}$ From the political constitutionality point of view we could interpret the first chapter of the Fundamental Law as a symbolic dethronization of the "invisible constitution" and the rehabilitation of the historical constitution. It demonstrates the returning to the traditional form of government by not even mentioning rule of law, and having the following instead: "We hold that the common goal of citizens and the State is to achieve the highest possible measure of well-being, safety, order, justice and liberty." The National Avowal is not only intended to lay down the emotional basis of the new constitutional identity, but it may play an important role in the interpretation of the constitution. According to Article R paragraph 3 of the Fundamental Law: "The provisions of the Fundamental Law shall be interpreted in accordance with their purposes, the National Avowal contained therein and the achievements of our historical constitution." The message of this triad of constitutional interpretation - especially when connected with the fourth amendment discussed later - is to replace the "invisible constitution", which served as a measure of fundamental rights activism.

If we sum up the criticisms of the previous constitution, it can be seen that the Fundamental Law incorporates the most important provisions that the old constitution lacked according to critics. Community-centered regulation is built in next to the human rights catalogue of the Fundamental Rights Charter; citizens' obligations also appear beside citizens' rights; among the legal interpretation requirements of courts common sense and public good appears, as well as the presumption of legal acts serving moral and economical purposes (Article 28). Strengthening the role of the state, the limits of selling national wealth, and the - much debated - pension rules and the proportional sharing of taxation also became parts of the Fundamental Law.

The new constitution shows an interesting dichotomy: "it identifies itself as the finisher of the system change - but it does not build continuity on the constitution of the past 20 years. [...] It suggests a returning to the historical roots of Hungarian statehood in its rhetoric, but it is connected to the democratic constitution of 1989 in its normative contents." ${ }^{17}$

The sharpest conflicts of the new constitutional system arose between the Constitutional Court and the government as it relates to the legislative branch, and appearing as constitution enacting power. The writers of the Fundamental Law intended to create a constitution "carved in granite". However, the democratic and professional deficit of the "revolutionary legislation", the "purposeless lawyering" of the Constitutional Court, and the "intriguing of globalist circles" hiding behind the Venice Commission forced the parliamentary majority to tailor the Fundamental Law to the political challenges through several amendments. After the fourth amendment, and only a few months before the 2014 elections, the constitutional conflicts have not ruled the political agenda anymore. If we want to draw a picture "after the war", we could 
say that the government considers the first stage of constitution-making closed, and it now intends to consolidate the achievements of the second constitutional revolution. The opposition thinks of a kind of "restorative constitution making", while the radical side argues in favor of returning to the constitutional fundamentals of 1989, and the moderates propose a reconciliation with the national-conservative side. Constitutional jurists try to process the changes through academic conferences and research projects. $^{18}$

\section{Constitutional CONFlicts OR 'CHECKS AND BAlances'?}

Unlike the old constitution, the Fundamental Law explicitly declares the principle of separation of powers: "the functioning of the Hungarian State shall be based on the principle of division of powers" (Article C paragraph 1). The new constitution - contrary to previous presumptions and the concept of the ad hoc committee in charge of preparing the new constitution - maintained the republican form of government, and did not make radical changes to the governmental structure. However, some shifts have happened in the relationship between constitutional institutions. As a new actor in the system of checks and balances the Budget Committee appeared which can significantly limit the actions of the parliament, because no central budget may be adopted without the consent of the Committee. Although the President did not acquire the right to dismiss the parliament (in times of serious constitutional or political crisis due to lack of confidence), as the preparatory committee first suggested, he is still capable of shortening the term of the parliament if the parliament does not adopt the central budget of the year until March 31. The previous constitution also included the right of the President to dismiss parliament if parliament does not elect a prime minister within 40 days of the first candidate being introduced. Beside the President's power of political veto (sending a bill back to parliament for reconsideration), the President's power of constitutional veto (sending the bill to the Constitutional Court if the President finds it unconstitutional) was broadened. However the Fundamental Law sets forth that if the President does not exercise his veto rights, he has to sign the bill into law within 5 days.

As for the government, the Fundamental Law strengthens the position of the Prime minister (chancellor type of government). The institution of the so-called "constructive no-confidence vote" was upheld. As a new constitutional regulation, besides the government, the Prime minister can now assign duties to the ministers. The inclusion of local governmental institutions and autonomous regulatory organs (with the power to issue decrees) in the Fundamental Law also adds a new player to the system of separation of powers.

The most important changes occurred with regards to the position of the Constitutional Court within the system of powers. During the first phase of the constitutiondrafting process many experts supported the idea of turning from the centralized (European) model of constitutional jurisdiction to the decentralized (American) model. According to these experts, a system of constitutional protection should have 
been created where the Curia (Supreme Court of Hungary) takes the role of the Constitutional Court, and lower level courts would have become the primary institutions of fundamental rights protection. The creation of a separate administrative court also came up. Eventually, the parliamentary majority didn't take the conflicts that would have come with the radical reform of constitutional protection and the judiciary, the de facto abolishing of the Constitutional Court, but many significant changes were made. ${ }^{19}$ With the constitutional amendments of 2010 and 2011 the governing majority assumed a dominant position in nominating judges to the Constitutional Court, limited the powers of the Court in the field of economic freedom, put the election of the president of the Court in the hand of the parliament, and finally raised the number of judges to 15 .

These steps however did not prevent the Constitutional Court from making decisions according to rule of law norms in politically sensitive cases. In December 2011 the Court annulled several provisions of the Media Act. ${ }^{20}$ The following year the Court decided on the conditions under which the Court can use arguments that the Court set forth in decisions made prior to the new constitution coming into force ${ }^{21}$ the Court ruled that it was unconstitutional to arbitrarily set the retirement age of judges at $62 ;{ }^{22}$ the Court also annulled the criminalization of homelessness; ${ }^{23}$ finally when reviewing the Act on the Protection of Families, the Court deemed the Act's definition of a family too narrow. ${ }^{24}$ The decisions of the Court clearly showed that the 'rule of law institutions' are still alive and well, and that the Court, accused of having a majority of judges loyal to Fidesz, is able to carry out the constitutional control over legislation passed by the governing majority.

Tensions increased in late 2012, early 2013, when the Court partially nullified the Transitional Provisions of the Fundamental Law, ${ }^{25}$ and then, initiated by the preliminary norm control request of the President of Hungary, ruled several provisions of the Act on the Electoral Process unconstitutional. ${ }^{26}$ These two decisions were in connection with each other, because the need for voters to register themselves before elections had been written into the Transitional Provisions by the second amendment of the Fundamental Law, therefore partial nullification gave the chance to carry out the constitutional review of the registration. ${ }^{27}$ Elaborating on the decision on the Transitional provisions the Court faced grave questions, such as whether the Constitutional Court has the competence to review the Fundamental Law itself and its amendments, and the question of which legal source category to put the Transitional provisions into. The firm practice of the Court was that the Court may not review the constitution itself, but the Court did not rule out the possibility of a review if the legal validity of the amendment is challenged. The Court based the possibility of reviewing the Transitional provisions on the assumption that the sovereign, by enacting the Fundamental Law, intended to create a stable, permanent constitutional system, defining the Fundamental Law's scope, contents and structure. The Court ruled that based on the criteria deriving from the Fundamental Law there may only be one single source of law on the top of the hierarchy of legal sources. The Transitional provisions disrupt this coherence, the Court argued, because the provi- 
sions intend to elevate multiple provisions to the top level, which are not built into the text of the Fundamental Law. It can cause uncertainty in the constitution if the contents and scope of the Fundamental Law is obscure or it can be defined multiple ways. "The Fundamental Law obliges the Constitutional Court to examine all those laws that break up the internal unity of the legal system, in particular the ones that violate the unity of the Fundamental Law itself. Accordingly it is not only a right but a constitutional obligation of the Constitutional Court to protect the Fundamental Law against any legislative decision that would hinder or deteriorate the enforcement of the provisions contained in the Fundamental Law, making its legal contents, scope and its position in the hierarchy of the sources of law, as well as the contents of the Fundamental Law as a constitutional standard uncertain. The Constitutional Court's obligation to protect the Fundamental Law includes the duty of protecting it as a single and unified document." ${ }^{28}$ The Constitutional Court made it clear, that without incorporation no new provision shall become part of the Fundamental Law. The "incorporation order" also means that the amendments shall not create insoluble contradictions between the regulations of the Fundamental Law. The decision set forth that "As appropriate, the Constitutional Court may even examine the free enforcement and the constitutionalization of the substantial requirements, guarantees and values of democratic States under the rule of law." ${ }^{29}$ The majority reasoning of the decision left open the possibility of reviewing the contents of constitutional amendments. These two decisions should have created a balance in the system of the separation of powers between the forces of political constitutionality and legal constitutionality. The parliamentary majority however considered it as the Constitutional Court crossing the Rubicon and violating fundamental political interests of the parliamentary majority, which had the mandate of voters. The parliamentary majority retreated in the case of voter registration but took up the hatchet in the case of constitutional amendments.

The Fourth Amendment not only incorporated most of the Transitional provisions in the Fundamental Law but also included several other regulations that have been previously deemed unconstitutional by the Court. The Amendment rearranged the system of the separation of powers, by attempting to reign in the scope of authority of the Constitutional Court. Indirectly, the Amendment prevented the Court from reviewing the text of all other amendments, except in case of a breach of procedural regulations. The Amendment also stipulated that the Court is bound to the content of the initiative, and that the Court may only broaden the scope of inquiry in the case of close connection; the Fourth Amendment also annulled all previous decisions of the Court, but it did not rule out the possibility for the Court to come to the same conclusion. The amendment set forth a close deadline for the constitutional review of court petitions, and created the partial publicity of the proceedings of the Constitutional Court. Understandably, the Fourth Amendment stirred up heated political debates, many have seen it as the end of the principle of separation of powers, and sanctions were demanded from the Council of Europe against Hungary for the breach of European Union law. 
THE RULE OF LAW-INSEPARABLE PART

OF THE CONSTITUTIONAL GULTURE

With the Fourth Amendment meant the constitutional confirmation of a notion of rule of law that held that the democratically elected parliament is the main constitutional power in a democratic state, and that the legislature having a constitutional power through its members, accepts no limits in exercising this right. The Court can review the constitutionality of the amendments but only from a procedural point of view. It means that if the parliament with a majority to amend the constitution thinks that the Court made a "bad" decision, it can overrule the Court's decision by making the annulled regulations a part of the Fundamental Law. Supporters of political constitutionalism believe that the legislators with democratic mandate are much more capable and have a stronger legitimacy to solve problems caused by "reasonable disagreements" within society. The judges of the Constitutional Court on the other hand ignore the majority opinion of society, and regularly represent minority opinions, that are not shared by the wider political community. Political constitutionalists believe that the substance of the constitution is not about the boundaries that the constitutional regulations enforce upon the legislator through the human rights catalogue, but about democratic decision-making which leaves the final decisions in the hand of elected politicians. As for the separation of powers, checks and balances are not constituted by the veto actors (e.g. the Constitutional Court), but by the parties competing in free elections. ${ }^{30}$

According to this argumentation, the constitution-making power of the legislative branch is theoretically unlimited, although it has to respect international ius cogens, the formal regulations guiding the process of adopting the constitution, and the integrity of the constitution (it shall not incorporate regulations that are in an insoluble conflict with the other regulations of the constitution).

Since in a democracy no power shall be unlimited, the constitution-amending power is not limitless either; other than the above-mentioned limits, it is bound by the stipulations of the current constitution, the Fundamental Law. This created the constitutional system of separation of powers in which the Constitutional Court as the protector of the Fundamental Law is obliged to stand up against any attempts to limit the effectiveness of a fundamental norm or attempts to hollow out the content of the constitution. The Constitutional Court has to function as a way of constitutional protection as long as it is allowed by the Fundamental Law and the eligible legal instruments. The review of the constitutional amendments shall not mean taking over the legislature's constitution-amending power. The Constitutional Court is obliged to respect the Fundamental Law and it has to make decisions based on it. At the same time, Parliament is responsible of respecting the Fundamental Law that itself crafted in order to maintain the rule of law. The Constitutional Court ruled that the regulations becoming parts of the Fundamental Law though amendments have to be built into the structure of the Fundamental Law (incorporation order) in a coherent manner. The amendments shall not create an insoluble contradiction within the Fundamental 
Law. The idea of coherence is a rule of law requirement based on Article B paragraph 1 of the Fundamental Law that the legislator has to respect. ${ }^{31}$

"The unified and coherent character of the constitution is not a concept for its own sake. It is a precondition of successful constitutional jurisprudence and is therefore the foundation of the constitution's legitimacy to make sure that the legal norm on the top of the hierarchy of legal sources is capable of being the foundation of a coherent Constitutional Court practice. It is worth noting that this is also in the interest of the constitution making body and society at large. Nothing can be the cornerstone of the legal system which is ambiguous and not stable and predictable. In every country coherence has to be provided by the constitutional court" (Csink-Fröhlich, 2013:5-6).

There is no democratic alternative to the rule of law, no effective governance may be carried out without stable constitutional foundations. Just as the historical constitution could not have been ruled out of the Hungarian legal culture, more than twenty years of the Constitutional Court's legal development cannot be entirely edited out from the constitutional culture either. The political elite of the system change cannot shift the full responsibility of their own inability or to counter an activist Constitutional Court. The Constitutional Court has no competence to rule on political decisions, but it does have the competence to rule on the constitutionality of the cases brought before the Court; this is the Court's constitutional obligation. If the parliament's super majority excludes financial and taxation matters from the jurisdiction of the Court, it severely endangers the rule of law and economic constitutionality. If the parliament - without solid theoretical foundation and driven by political necessities - regularly overrules the Court's decisions by "over-amending the Fundamental Law" for policy reasons, this might undermine the coherence of the constitution itself, and make parliament subject to the accusation of abusive constitutionalism. ${ }^{32}$ In the system of separation of powers, the constitutional requirement of cooperation has to prevail. In the case of a parliamentary super majority, the Constitutional Court, the only real counterbalance to the legislative body, bears a special responsibility. It is more visible in a consolidated time how much the national parliament and the government has to rely on the guardian of constitutionality, the Constitutional Court. It is the common interest of constitutional institutions - I should say it is a national interest - that the values and the normative contents of the Fundamental Law win the sympathy of the people so that they themselves are willing to follow the rules. If we sacrifice rule of law values and constitutional stability on the altar of ad hoc political interests, the whole society may have to pay a price which is simply not worth it. In a democratic rule of law state, separation of powers has to give answer not to the question of who defeats whom, but to the substance of the system of constitutional responsibility which ultimately serves the common good. Instead of restricting certain competences of the Constitutional Court or overruling some of its concrete decisions, it is preferable to establish procedures, which enable the government or the parliament to more effectively channel policy considerations and other public interests (eg. a sustainable budget) in the Court's decision making process. A good example for this 
kind of measure is Article 24 paragraph 7 of the Fundamental Law, introduced by the fourth amendment. ${ }^{33}$

\section{The Constitutional Court in the context \\ OF THE SUPRANATIONAL EUROPEAN LEGAL ORDER}

Hungary's European reintegration, the adaptation of "western democratic values" and the unconditional acceptance of the primacy of European community law was the entry ticket into the "Western club". Now, when the future operation of club "Europe" is at stake (cf. Sulyok, 2014:48), it is time to review what a fair and sustainable balance is between national and European community interests. It is time to look for legal notions and procedures through which this balance can be ascertained in concrete cases.

The importance of this problem was raised by the development of European Union itself: with the Treaty of Lisbon (signed in 2007, entered into force in 2009) the Union has reached a "critical mass", staying between being a community of states and a federal state. This makes it necessary for the Member States to delineate the boundaries of their sovereignty (cf. Sulyok, 2014:46). The general rule set out by the European Court of Justice (ECJ) is that the Member States may not even refer to their constitution in order to avoid the execution of European Union law. The same Treaty of Lisbon which consolidated the European Union also introduced an explicit restriction on the application of community law: the concept of "national identity". As the amended Article 4 Section 2 of the Treaty on European Union stipulates:

"The Union shall respect the equality of Member States before the Treaties as well as their national identities, inherent in their fundamental structures, political and constitutional, inclusive of regional and local self-government. It shall respect their essential State functions, including ensuring the territorial integrity of the State, maintaining law and order and safeguarding national security. In particular, national security remains the sole responsibility of each Member State."

The question of how to define the concept of "national identity" is sensitive: the interpretation of sovereignty and identity decides where the boundary for the primacy of European Union law lies and where that core of competence is that the member state may keep for themselves (Szakály, 2015:35). For this reason, the question whether the ECJ or the member state's constitutional courts (supreme courts) is to decide the content of a member state's national identity, is crucial for the sovereignty of the Member States. It is for this reason, that national constitutional courts, beside their traditional role of enforcing the constitution against the domestic lawmaker and courts, gain a new and important role in the context of the supranational European legal order.

In the case of Hungary, the switch from the 1989 Constitution to the Fundamental Law - a few years after the Treaty of Lisbon entered into effect - ended the era of politically neutral constitutionality and set a normative base for articulating Hungary's constitutional identity. The main foundations for this undertaking are the principles 
for interpreting the Constitution in Article R paragraph 3 referring to National Avowal and the achievements of our historical constitution, furthermore the interpretation principles for judges set forth in Article 28 (the presumption that laws serve moral and economical purposes which are in accordance with common sense and the public good). These rules embrace Hungary's historic perspective in interpreting national identity and bring a characteristic value-orientation to build upon.

Based on all these, a challenge has been set for the Constitutional Court, namely to develop a new test for the protection of "national identity" through which the core of national sovereignty - which is untouchable for European community law - can be delineated. The first opportunity to commence this task could have been the constitutional review of the Act on the promulgation of the Lisbon Treaty, however, the majority of the Court did not deal with this notion at that time. ${ }^{34}$

A new development in this field is the 22/2016. (XII. 5.) ABH Constitutional Court Decision on the interpretation of Article E) Section 2 of the Fundamental Law. In this decision, the Court declared that " $[\mathrm{t}]$ he Constitutional Court, exercising its competences based on a petition containing a request to do so, can review whether the joint exercise of competences based on Article E) Section 2 of the Fundamental Law infringes on human dignity, other fundamental rights, the sovereignty of Hungary, or the identity based on its historic constitution." This can be considered as a great step in the direction of unfolding and protecting Hungary's national (constitutional) identity, so I agreed with the merit of the decision, however, the majority's reasoning left a series of constitutional questions unanswered. It is not yet clear - among others - what forms of "joint exercise of competences" may be reviewed, in which competences of the Court and what legal consequences can be established if the Court finds the violation of one of the protected norms. The reasoning of the decision - in line with the theoretical considerations which I previously mentioned - sets an important general thesis regarding the notion of "constitutional identity", stipulating that the content thereof shall be construed case-by-case, based on the whole and on specific regulations of the Fundamental Law, as prescribed in Article R paragraph 3, in accordance with the National Avowal and with the achievements of our historical constitution. ${ }^{35}$

Practically it is the first declaration of the National Avowal that states that " $[\mathrm{w}] \mathrm{e}$ are proud that one thousand years ago our king, Saint Stephen, built the Hungarian State on solid foundations, and made our country a part of Christian Europe.” King Saint Stephen made a decision over one thousand years ago and the Fundamental Law pledges symbolic continuity with his decision. In Article E) of the Fundamental Law, this commitment goes way beyond the symbolic level. Article E) paragraph 1 stipulates that " $[\mathrm{i}] \mathrm{n}$ order to achieve the highest possible measure of freedom, well-being and security for the peoples of Europe Hungary shall contribute to the achievement of European unity." These provisions of the Fundamental Law imply that European identity is also part of the Hungarian constitutional identity.

When a member state transfers parts of the exercise of its sovereignty to the institutions of the European Union, the citizens of the affected Member States have to 
be involved in the direct decision-making. Nevertheless, on the one hand, it would not be reasonable, nor would it be feasible to hold a referendum on each - possibly disputed - measure of the institutions of the European Union. On the other hand, the constitutional courts of the Member States may be capable to protect - constantly, cost-effectively and with due foresight - the most eminent circle of the national interest of their country.

Hungary has started to go down this road. The Constitutional Court - when adequate cases come by where the application of national constitutional identity seems necessary - shall wisely further develop the notion in order that Hungary remain in the "club" in a way which benefits both the club member and the club. How should the Hungarian Constitutional Court serve this task? Firstly, the Court shall act according to its competences established by the Fundamental Law and by the Act on the Constitutional Court. Secondly, it shall also take into account European community law, in a constitutional dialogue with the ECJ. Thirdly, the historic dimension, the constitutional traditions of Hungary, the achievements of the historical constitution shall be taken into serious consideration when ascertaining the exact constitutional principles and values to be protected. At the same time, fourthly, the Court shall enforce the constitutional identity of Hungary faithfully to the Fundamental Law and within the framework set forth thereby. The Constitutional Court's derivation from the Fundamental Law - adopted by the constitution making body - would amount to an activism that not only infringes on the principle of the rule of law, but also on the principle of popular sovereignty.

\section{Notes}

1 The executive branch that is strongly tied together with the legislature, based on the authorization they won at the elections, often criticized the Constitutional Court, saying that the Court limits the functioning of the most important representative of people's sovereignty. The fundamental dilemma of constitutional jurisdiction as counter-majoritarian activity is: on what basis and to what extent can a non-representative body overrule the decisions of the parliament, which has a direct legitimacy (Dorsen et al., 2003:108-109).

2 31/1990 (XII. 18.) ABH Constitutional Court Decision.

3 Constitutional review of Acts adopted by the Parliament but not yet signed by the President of the Republic and not yet published in the Official Gazette.

4 38/1993 (XII. 18.) ABH Constitutional Court Decision.

5 8/1992 (I. 30.) ABH Constitutional Court Decision.

6 28/1995 (V. 19.) ABH Constitutional Court Decision.

7 23/1990 (X. 31.) ABH Constitutional Court Decision.

8 Basically the legitimacy and effectiveness of constitutional jurisprudence is questioned by University College London professor Richard Bellamy in his recently published book (Bellamy, 2007). Among Hungarian authors Pócza Kálmán (Pócza, 2012) and Antal Attila (Antal, 2013) wrote on the subject.

9 Day 12 of the 1991 autumn session of the Parliament, 8 October 1991. In: Országgyúlési Értesítô 19901994, 10656-10658.

10 In the first part of his book G. A. Tóth gives a good summary on the academic standpoints concerning activism, with special regard to the criticisms by Tamás Gyôrfi, Béla Pokol, János Kis, and Gábor Halmai (Tóth, 2009:15-30). 


\section{Civic Review · Vol. 13, Special Issue, 2017}

11 The introduction of this concept in the political discourse was done by Gyula Tellér, who characterized the socialist-liberal coalition, which followed the first freely elected government, the following way. "There were enormous economic and social forces behind the coalition parties of 1994. On one hand, the financial-administrative apparatus with the structure moving and financing the economy built in the last 20 years according to the recipe of the International Monetary Fund, limiting the scope of action of every government: the three circles of usury; on the other hand, the party clientele of MSZP with its network concentrating significant finances and connections: the "clotted structures". On the surface almost nothing could be seen from these deeply working forces that determined the whole course (Tellér, 1999:51).

12 According to Béla Pokol "However big of a legislative majority wipes off the previous government and takes control representing the voters' will, its hands are tied by the regulations written in the twentythousand pages long collection of the Constitutional Court's decisions, which can be interpreted multiple ways; therefore no government can be sure if they can carry out their will" (Pokol 2011:451).

13 In the aforementioned study Béla Pokol gives suggestions regarding the more exact contents of constitutional rights and obligations, the significant rearrangement of the Court's functioning and scope of jurisdiction, the rethinking of the judicial hierarchy and the appointment of judges, and such guarantees of the interpretation of the new constitution, which can limit the use of the "invisible constitution". (Pokol, 2011: 453-455.

14 Csaba Varga gives a very critical description of the Constitutional Court's responsibility in tipping the balance of rights and obligations by overemphasizing the citizen's rights, making the state a public enemy, emptying the law by stripping it of its morals, and rehabilitating the law of the law-denying past. He thinks that rule of law "gave primary protection to the former regime's legal status, players, and rights acquired by them; and by interpreting the present as something that stems from the past uninterrupted, it helped the legal, political, social, and economic survival of the forces of the forces of post-communism... through the theoretical and insensitive legal practice of a retiring scholar it dismissed the virtues of experience and practice from law" (Varga, 2011:488-489).

15 Bruce Ackerman described the situation this way, when one single political power has got enough majority to adopt a constitution, and no other player with veto right can stop them from reshaping the political rules of play to their own image (Ackerman, 1993).

16 Péter Szigeti expressed his concerns about this ideological foundation in one of his papers: "The "National Avowal" represents a break with the ideological neutrality of the state, because it raises the historical-value-perception, the values, and the ideology of the Hungarian right wing to a constitutional level. This ideological base is not at all innocent, and one can never know, what they are going to build on this foundation in the future. Will denying the legal continuity of 46 years bring the logic of "sinful era - sinful system - sinful organizations - sinful individuals?” Putting history to trial?” “...the concept based on rule of law and division of powers that we used for twenty years have been replaced by a new course-building, gouvernalistic state of power" (Szigeti, 2013:535).

17 This contradiction is even more obvious if we take into account that the preamble of the Fundamental Law declares the 1949 constitution "invalid", but paragraph 2 of the Closing provisions is in direct opposition with this, declaring that the Fundamental Law has been adopted with regards to the procedural regulations set forth in the replaced constitution (Jakab-Sonnevend, 2013:122, 125).

18 The opposition does not consider the Budgetary Committee a real constitutional balance, because its composition (presidents of the National Bank, the State Audit Office, and the Committee) ensures the majority of Fidesz for a long time. They think about its actual functioning, that in the case of a different political composition of the parliament, it can create the possibility of obstructing the government's work, and even forcing a new election.

19 The strong position of the Constitutional Court was disliked mainly by the former members of the Antall-government, but among the leaders of Fidesz - especially the Speaker of the Parliament. Many thought, that members of parliament, who won in the election, should decide the important questions of society, rather than having a small group of people "read form the constellation of stars, the guts of animals and the bones of birds, what the god of constitutionalism wishes to say to the mortal people". 


\section{István Stumpf: The Hungarian Constitutional Court's Place in the...}

The governing majority feared that the abolition of the Constitutional Court would mean the abolishment of democracy to the outside world, and that courts of law are not prepared for constitutional jurisdiction. By creating the Curia, the government created the grounds for dismissing the president of the Supreme Court; the National Office for the Judiciary and its president elected for nine years took over the control over the judicial system.

20 With this decision the Court excepted print and online media from the scope of the Media act, abolished the institution of the "media commissioner", deemed the regulation of journalist's source protection unconstitutional, and partially limited the investigative powers of the National Media and Infocommunications Authority.

21 22/2012 (V. 11.) ABH Constitutional Court Decision.

22 33/2012 (VII. 17.) ABH Constitutional Court Decision.

23 38/2012 (XI. 14.) ABH Constitutional Court Decision.

24 43/2012 (XII. 20.) ABH Constitutional Court Decision.

$2545 / 2012$ (XII. 29.) ABH Constitutional Court Decision.

26 1/2013 (I. 7.) ABH Constitutional Court Decision.

27 The Court has 30 days to decide on a preliminary norm control case. Because of Christmas and New Year's holidays this time was reduced to half, and they had to decide on the constitutional status of the Transitional Provisions as a preliminary question. Government politicians created conspiracy theories: "it would take too much of malice for me to think that the Constitutional Court only deemed the Transitional Provisions unconstitutional in order to kick out the constitutional leg of the election registry" (interview with László Kövér in Heti Válasz).

28 Decision 45/2012 of the Constitutional Court. English version available: www.mkab.hu/letoltesek/ en_0045_2012.pdf (accessed 10 July 2014).

29 The decision was adopted with the concurring opinions of Holló András and Stumpf István, and with the dissenting opinions of István Balsai, Egon Dienes-Oehm, Barnabás Lenkovics, Péter Szalay and Mária Szívós.

30 In a recent publication, Béla Pokol added an international dimension to the arguments of political constitutionalists. "[...] the decisions of the ECHR of Strasbourg, the regulations of the global constitutional-advisory organizations, and the constitutionalized "general" international law would take control over the constitution itself, its amendments, and the constitution making power. Thus, the circle would close, and the most important characteristic of a state, the power to adopt a constitution, would cease to exist." In the end of his article, Béla Pokol envisions the threat of a forming global constitutional oligarchy. Jogelméleti Szemle, December 2013.

31 I summarize the practice of the Court and the views concerning the coherence of the Constitution in my concurring opinion attached to the Court's decision 45/2012, and in the dissenting opinion I attached to the decision concerning the fourth amendment.

32 In one of his recent works American legal scholar David Landau has cited Hungary - among Venezuela and Columbia - as an example for abusive constitutionalism. University of California, Davis Law Review, vol. 47, 189-260, lawreview.law.ucdavis.edu/issues/47/1/Articles/47-1_Landau.pdf.

33 "The Constitutional Court shall hear the legislator, the initiator of the Act or their representative and shall obtain their opinions during its procedure defined by cardinal Act if the matter affects a wide range of persons. This stage of the procedure shall be open to the public." - Unfortunately, despite the rule being in force since 1 April 2013, the Constitutional Court has not used it so far.

${ }_{34}$ 143/2010. (VII. 14.) AB of the Constitutional Court Decision. The Court rejected the petition submitted by a private person aimed at establishing the unconstitutionality of the Act on the promulgation of the Lisbon Treaty. It was only the concurring opinion of László Trócsányi that drew attention to the importance of the notion of constitutional identity.

35 Unfortunately, the reasoning of the decision fails to implement this thesis in two instances right after it is declared (see: paragraphs [66]-[67]). In the first instance, the decision accepts certain elements to be part of the constitutional identity, which are directly received from a decision of the German Constitutional Court. In the second instance, the decision practically declares that Hungary's constitutional identity does not derive from the Fundamental Law, the latter only recognizes it. 


\section{Civic Review · Vol. 13, Special Issue, 2017}

\section{REFERENGES}

Ackerman, Bruce (1993): We the People. Foundations. Harvard University Press, Cambridge (MA), 17.

Antal, Attila (2013): Politikai és jogi alkotmányosság Magyarországon [Political and Legal Constitutionality in Hungary]. Politikatudományi Szemle, no. 3.

Bellamy, Richard (2007): Political Constitutionalism. A Republican Defense of the Constitutionality of Democracy. Cambridge University Press, Cambridge, https://doi.org/10.1017/CBO9780511490187.

Bihari, Mihály (2005): A magyar politika 1944-2004. Politikai és hatalmi viszonyok [Politics in Hungary 19442004. Political and Competence Relations]. Osiris Kiadó, Budapest, 333-413.

Brunner, Georg (1992): Development of a Constitutional Judiciary in Eastern Europe. Review of Central and Eastern European Law, no. 6, 539.

Csink, Lóránt - Fröhlich, Johanna (2013): A régiek óvatossága. Megjegyzések az Alaptörvény negyedik módosításának javaslata kapcsán [Carefulness of the Wise. Notes Regarding the Fourth Amendment to the Fundamental Law]. Pázmány Law Working Papers, no. 1, 5-6.

Dorsen, Norman et al. (2003): Comparative Constitutionalism. Thomson-West, St.Paul, 108-109.

Halmai, Gábor (1994): A véleményszabadság határai [Limits of Free Speech]. Atlantisz Kiadó, Budapest, 85.

Halmai, Gábor (2000): Bevezetés. Az aktivizmus vége? [Introduction. The End of Activism?]. In: A megtalált alkotmány. A magyar alapjogi bíráskodás kilenc éve [The Constitution Found. Nine Years of Constitutional Adjudication]. Ed. Gábor Halmai, Fundamentum Könyvek, Indok Kiadó, Budapest, 12.

Jakab, András - Sonnevend, Pál (2013): Kontinuitás hiányosságokkal: Az új magyar Alaptörvény [Continuity with Deficiencies: The New Fundamental Law]. In: Állam és jog. Kodifikációs kihíuások napjainkban [State and Law: Recent Challenges of Codification]. Eds. Zsuzsanna Fejes et al., Magyar Jog- és Államtudományi Társaság - Gondolat Kiadó, Szeged-Budapest, 122, 125.

Kéri, László (2010): A rendszerváltás krónikája 1998-2009 [The Transformation of the System 1998-2009]. Kossuth Kiadó - Népszabadság, Budapest.

Kis, János (2000): Alkotmányos demokrácia. Három tanulmány [Constitutional Democracy: Three Studies]. Indok Kiadó, Budapest, 112-114.

Kukorelli, István (2006): Tradíció és modernizáció a magyar alkotmányjogban [Tradition and Modernization in Hungarian Constitutional Law]. Századvég Kiadó, Budapest, 102.

Paczolay, Péter (2013): „Jó állam - jó jog” [Good State - Good Law]. In: Állam és jog. Kodifikációs kihívások napjainkban [State and Law: Recent Challenges of Codification]. Eds. Zsuzsanna Fejes et al., Magyar Jog- és Államtudományi Társaság - Gondolat Kiadó, Szeged-Budapest, 13.

Pócza, Kálmán (2012): Alkotmányozás Magyarországon és az Egyesült Királyságban [Constitution-making in Hungary and in the United Kingdom]. Kommentár, no. 5, 35-50.

Pokol, Béla (1992): Aktivizmus és az Alkotmánybíróság [Activism and the Constitutional Court]. In: Magyarország Politikai Évkönyve [The Political Diary of Hungary]. Eds. Sándor Kurtán et al., DKMK, Budapest, 154.

Pokol, Béla (2011): Demokrácia, hatalommegosztás és az állam cselekvő́képessége [Democracy, Separation of Powers, and the Capacity of the State]. In: Húsz éve szabadon Közép-Európában. Demokrácia, politika, jog [20 Years of Freedom in Central-Eastern Europe: Democracy, Politics and Law]. Ed. János Simon, Konrad Adenauer Alapítvány, Budapest, 451, 453-455.

Posner, Richard A. (2008): How Judges Think. Harvard University Press, Cambridge (MA).

Smuk, Péter (2011): Magyar közjog és politika 1989-2011 [Hungarian Public Law and Politics]. Osiris Kiadó, Budapest.

Sólyom, László (2000): A „nehéz eseteknél” a bíró erkölcsi felfogása jut szerephez. Sólyom Lászlóval, az Alkotmánybíróság elnökével Tóth Gábor Attila beszélget [It is the moral assessment of the judge that prevails in hard cases - interview of Attila Gábor Tóth with László Sólyom, president of the Constitutional Court]. Fundamentum, 1997/1. In: A megtalált alkotmány. A magyar alapjogi bíráskodás kilenc éve. Ed. Gábor Halmai, Fundamentum Könyvek, Indok Kiadó, Budapest, 395.

Sólyom, László (2001): Az alkotmánybiráskodás kezdetei Magyarországon [The Beginning of Constitutional Adjudication in Hungary]. Osiris Kiadó, Budapest, 686-687, 699, 708. 


\section{István Stumpf: The Hungarian Constitutional Court's Place in the...}

Stumpf, István (2013): Hatalommegosztás és államszervezet az új Alaptörvényben [Separation of Powers and the Organization of the State in the New Fundamental Law]. In: Állam és jog. Kodifikációs kihívások napjainkban [State and Law: Recent Challenges of Codification]. Eds. Zsuzsanna Fejes et al., Magyar Jog- és Államtudományi Társaság - Gondolat Kiadó, Szeged-Budapest, 23-40.

Sulyok, Márton (2014): Nemzeti és alkotmányos identitás a nemzeti alkotmánybíróságok gyakorlatában [National and Constitutional Identity in the Jurisprudence of National Constitutional Courts]. In: Nemzeti identitás és alkotmányos identitás az Európai Unió és a tagállamok viszonylatában. Ed. Mira Anna Jakó, Szegedi Tudományegyetem Állam- és Jogtudományi Kar Nemzetközi és Regionális Tanulmányok Intézete, Szeged, 44-62.

Szakály, Zsuzsa (2015): A történeti alkotmány és az alkotmányos identitás az Alaptörvény tükrében [The Historic Constitution and the Constitutional Identity in the Light of the Fundamental Law]. Pro Publico Bono - Magyar Közigazgatás, no. 2, 24-38.

Szigeti, Péter (2013): Az alaptörvény karaktere államelméleti és alkotmányjogi aspektusokból [The Character of the New Fundamental Law: Constitutional Law and State Theory Observations]. In: Tanulmányok a 70 éves Bihari Mihály tiszteletére. Universitas, Győr, 533, 535.

Tellér, Gyula (1999): Hatalomgyakorlás az MSZP-SZDSZ-koalíció idején [Exercising Power in time of the MSZP-SZDSZ Coalition]. Kairosz Kiadó, Budapest, 51.

Tóth, Gábor Attila (2009): Túl a szövegen. Értekezés a magyar alkotmányról [Beyond the Text: Memoire About the Hungarian Constitution]. Osiris Kiadó, Budapest, 17, 15-30, 24.

Varga, Csaba (2006): Jogmegújítás alkotmánybíráskodás útján? [Developing Law Through Constitutional Adjudication?]. In: Formatori Iuris Publici Studia in Honorem Geisea Kilényi Septuagenarii: Ünnepi kötet Kilényi Géza professzor 70. születésnapjára. Eds. Barnabás Hajas, Balázs Schanda, Szent István Társulat, Budapest, 540 .

Varga, Csaba (2011): Küzdelem a jogért [Struggle for Law]. In: Húszéve szabadon Közép-Európában. Demokrácia, politika, jog [20 years of freedom in Central-Eastern Europe: Democracy, Politics and Law]. Ed. János Simon, Konrad Adenauer Alapítvány, Budapest, 488-489. 